\title{
MOSFET 漏/源电阻的半经验模型
}

\author{
柯导明*，杨建国，常红，杨菲，胡鹏飞，彭雪扬，孙乐尚，吴笛 \\ 安徽大学电子信息工程学院, 合肥 230601 \\ * 通信作者. E-mail: kedaoming@sohu.com
}

收稿日期: 2016-11-05; 接受日期: 2017-02-06; 网络出版日期: 2017-07-14

国家自然科学基金 (批准号: 61076086, 61376098) 资助项目

\begin{abstract}
摘要 本文基于微元电阻和积分中值定理导出了仅有 3 个待定参数的超深亚微米 MOSFET 的 漏/源电阻模型, 而这 3 个参数可以用多元线性回归方法得到. 论文用数值模拟数据, 拟合了衬底掺 杂是 $1 \times 10^{15} \sim 1 \times 10^{16} \mathrm{~cm}^{-3}$ 、沟道长度是 $45 \sim 2000 \mathrm{~nm}$ 的平面 nMOSFET 和 nLDD-MOSFET 的 漏/源电阻模型的待定参数, 得到了它们的半经验公式, 最大误差仅有 $9.5 \%$. 漏/源电阻模型和它的 半经验公式计算结果表明, 漏/源电阻仅与漏/源 pn 结结深、电阻率和沟道到漏/源电极长度有关, 沟道长度、叠栅长度和电极长度对它的影响可以忽略. 由于这个半经验表达式形式简单、精度高、物 理概念清晰、易于提取参数, 所以它既可以用于 MOSFET 的特性分析又可以用于电路模拟器.
\end{abstract}

关键词 MOSFET 的漏/源电阻, 半经验公式, 微元电阻, 数值模拟

\section{1 引言}

由于 MOSFET 的漏/源电阻不能按比例缩小, 因此在小尺寸 MOSFET 的寄生效应中, 漏/源电阻 的研究一直占有重要的作用. 目前已经研究出了多种计算漏/源电阻的方法, 其中最经典的方法是沟 道电阻法 ${ }^{[1]}$. 虽然这个方法至今仍是被广泛采用的最重要的方法, 但是这一方法需要测量一系列不同 沟道长度的 MOSFET 伏安特性, 因此显得复杂繁琐. 为此许多研究者陆续研究了众多的新方法, 如有 限元或有限差分的数值计算法 ${ }^{[2]}$ 、用寄生结电流改进沟道电阻法 ${ }^{[3]}$ 、积分法 ${ }^{[4]}$ 、表面势方法 ${ }^{[5]}$ 和半 解析方法 [6] 等. 这些计算方法使得漏/源电阻的计算更加准确, 但是其计算过程或者十分复杂, 或者 没有给出明确的解析表达式, 计算量大且难以给出明确的物理概念, 例如数值计算法对于集成电路设 计者而言, 则无法将这些方法直接用于电路的设计中, 通常只能从电路设计成功后的模拟中, 才能推测 出漏/源电阻的数值, 这给器件和电路设计带来了诸多不便. 为了克服这一缺点, 本文基于电阻形成的 物理机制、MOSFET 漏/源电阻的数值模拟结果和多元线性回归法, 提出了沟道长度是 $45 \sim 2000 \mathrm{~nm}$

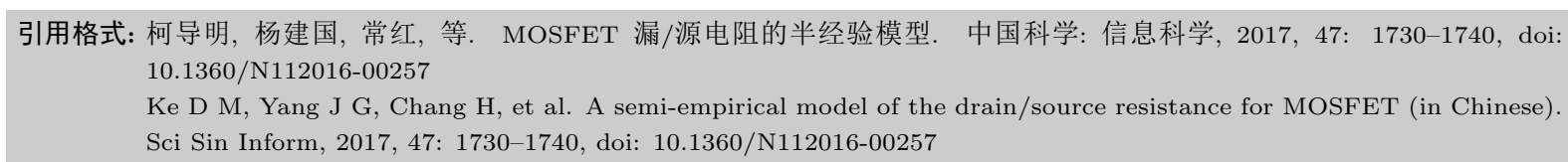




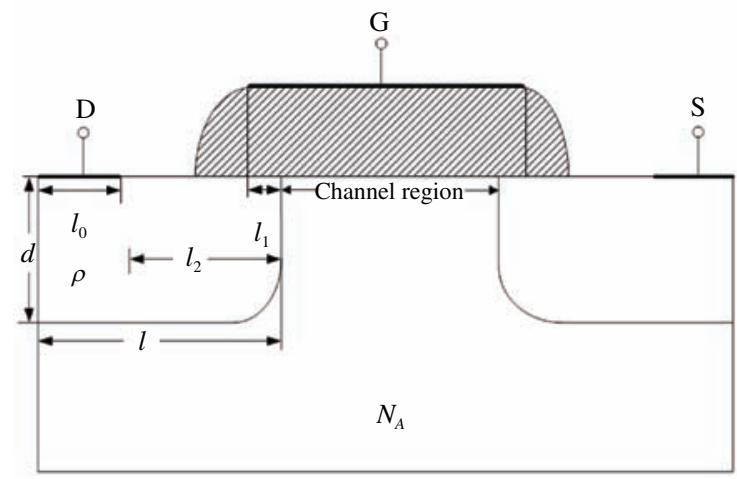

(a)

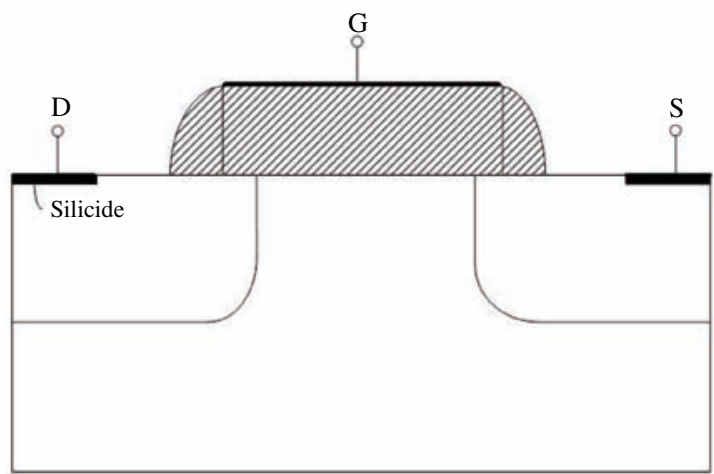

(b)

图 1 MOSFET 的结构图. (a) 计算所用 MOSFET; (b) 有硅化物的现代 MOSFET

Figure 1 The structure diagram of MOSFET. (a) MOSFET used in the calculation; (b) modern MOSFET with silicide

的 nMOSFET 漏/源电阻的半经验模型, 该模型使用的计算公式形式简单、精度高、参数少, 可直接用 于器件分析和电路设计.

文章内容安排如下: 第 2 节分析了 MOSFET 漏/源几何尺寸和电阻率与电阻的关系, 提出了超深 亚微米 MOSFET 漏/源电阻的半经验计算公式; 第 3 节用多元线性回归算法求解了经验参数, 并计算 了一个求经验因子值例子; 第 4 节用例子验证了所提出的计算公式以及由此得到的几点有益的结论; 第 5 节总结了本文内容.

\section{MOSFET 漏/源电阻的半经验公式}

平面 MOSFET 如图 1(a) 所示, 现代 MOSFET 中为了减小漏/源电阻通常会在漏和源区中引入 一层薄的硅化物, 如图 1(b) 所示由于硅化物很薄, 电阻很小, 可以将这一层硅化物当作接触电阻的一 部分, 图 1(b) 所示的 MOSFET 可以简化为图 1(a) 的结构, 只不过电极的位置变大了 ${ }^{[1]}$, 下面的计算 中仍将以图 1(a) 的结构来推导和计算漏/源电阻. 图 1(a) 中, $l_{1}$ 是叠栅长度; $l_{2}$ 是漏/源 $p n$ 治金结边 界至漏/源电极的长度; $l$ 是漏/源区总长度; $d$ 是冶金结结深; $\rho$ 是漏/源区掺杂的电阻率; $l_{0}$ 是漏或源 电极长度.

图 2 是漏/源区电阻 $R_{\mathrm{DS}}$ 计算的示意图, 其大小与漏/源结冶金结尺寸相同. 下面用此图推导漏/源 电阻的拟合公式. 图 2 中 $\mathrm{A}$ 是沟道末端, 叠栅下面是积累层 $\mathrm{A}^{\prime}$, 载流子由 $\mathrm{AA}^{\prime}$ 流入 (出) 漏/源区, 从 漏/源电极 $\mathrm{BB}^{\prime}$ 流出 (入), 载流子运动的途径如图 2 虚线所示, 因此电阻 $R_{\mathrm{DS}}$ 是一个扩展电阻 ${ }^{[7]}, \mathrm{AA}^{\prime}$ 与 $\mathrm{BB}^{\prime}$ 分别是 $R_{\mathrm{DS}}$ 的两个电极. $R_{\mathrm{DS}}$ 包含了两个部分: 漏/源区本征电阻和 $\mathrm{BB}^{\prime}$ 的接触电阻. 接触电 阻通常与金 - 半特性界面和电极的面积有关. 实际计算中引入与几何结构无关的比接触电阻 $\rho_{\Omega}$, 由理 论计算值加上测量修正共同决定, 漏/源电极的接触电阻为 $\rho_{\Omega}$ 乘以电极面积 ${ }^{[8]}$, 因此这里不讨论接触 电阻假设 $\mathrm{BB}^{\prime}$ 是欧姆接触, $\rho_{\Omega}$ 只是漏/源区本征电阻.

漏/源区是重掺杂, 传统的深结 MOSFET 中可以用均匀电阻率代替该区域电阻率计算漏/源区本 征电阻 ${ }^{[7]}$. 现代浅结 MOSFET 中, 用先进的工艺如晶片的非晶化处理、高剂量离子注入和快速退火 等方法, 保持漏/源区电阻率基本恒定, 通常可以认为该区域电阻率基本上是均匀的 ${ }^{[9]}$. 因此下面的计 算中认为漏/源区是均匀电阻率. 这里需要注意, 漏/源区的杂质虽然是均匀的, 但是由于横向扩散与纵 向扩散系数不同, 叠㮽下面冶金结附近的杂质浓度较漏/源区内部淡一些, 因而在边界有一梯度, 漏/源 


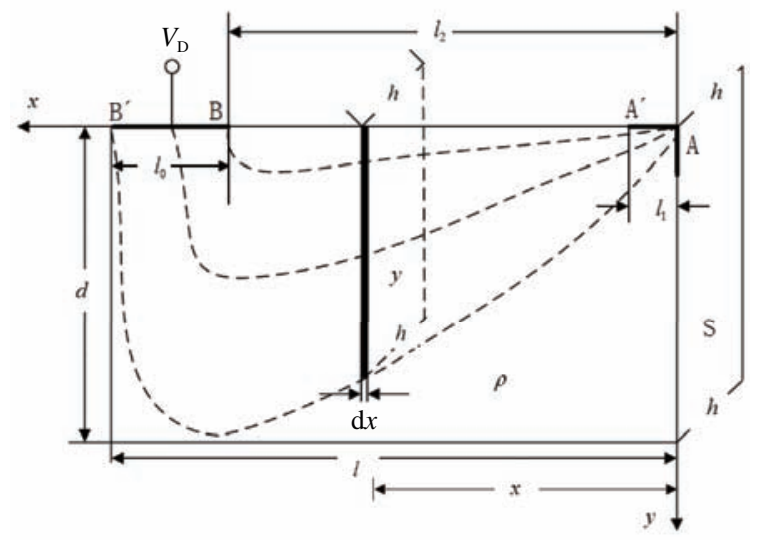

图 2 漏/源微分电阻示意图

Figure 2 The schematic diagram of drain / source differential resistance

区的杂质并不完全是均匀的 $[7,9]$.

$\mathrm{AA}^{\prime}$ 与 $\mathrm{BB}^{\prime}$ 之间是非均匀电场, 需要用微元法计算这个电阻. 取一微元如图 2 所示, 则得到微元 电阻是

$$
\mathrm{d} R_{\mathrm{DS}}=\rho(x) \frac{\mathrm{d} x}{y h},
$$

其中 $\rho(x)$ 是微元电阻率. 前面已经分析, 电阻率在叠㮽下面冶金结边界附近有一梯度, 因此 $\rho(x)$ 并不 是常数, 而是位置的函数. $h$ 是电阻的截面宽度, 单位是 $\mathrm{cm}$. 对式 (1) 积分, 得到

$$
R_{\mathrm{DS}}=\int_{\mathrm{AA}^{\prime}}^{\mathrm{BB}^{\prime}} \rho(x) \frac{\mathrm{d} x}{y h} \text {. }
$$

因为不知道载流子运动路径 $y$ 服从何种规律, 积分限 $\mathrm{AA}^{\prime}$ 和 $\mathrm{BB}^{\prime}$ 也不是一个常数, 所以式 (2) 实际上 是一个复杂的线积分, 并不容易求出. 为此引入经验参数来简化式 $(2)$, 导出 $R_{\mathrm{DS}}$ 计算公式.

为了分析 $R_{\mathrm{DS}}$ 与物理参数和漏/源区几何尺寸的关系, 用数值模拟软件 silvaco 计算了沟道长度为 45 2000 nm MOSFET 的伏安特性, 衬底掺杂为 $1 \times 10^{15} \mathrm{~cm}^{-3}$, 根据伏安特性提取了漏/源电阻 $R_{\mathrm{DS}}$ 随着物理参数和漏/源区几何尺寸变化的情况, 然后用修正沟道电阻法 (具体方法见 3.1 小节) 提取了 $R_{\mathrm{DS}}$. 根据仿真结果可以得到如下结论:

(1) $R_{\mathrm{DS}}$ 与电极 $\mathrm{BB}^{\prime}$ 和 $l_{1}$ 的长度近似无关, 因此式 (2) 的积分区间可设为 $\left[0, l_{2}\right]$;

(2) $R_{\mathrm{DS}}$ 与结深 $d$ 的关系不像线性电阻那样成反比, 而是与 $d^{\beta}$ 成反比, 因此可以设图 2 中 $y=$ $k_{1}(x) d^{\beta}$

(3) $R_{\mathrm{DS}}$ 正比于 $\rho^{\alpha}$, 即 $R_{\mathrm{DS}}=k_{2}(x) \rho^{\alpha}$. 其原因有两个: 首先是载流子在漏/源区除了漂移外, 还 有扩散, 各处浓度并不相等; 其次是冶金结边界处由于横向扩散, 杂质浓度要低于内部浓度. 这两个原 因导致用于计算电阻的均匀掺杂电阻率不是掺杂电阻率 $\rho$, 而是 $\rho^{\alpha}$.

取 $h$ 为单位长度, 将上述 3 个结论代入式 (2) 得到

$$
R_{\mathrm{DS}}=\int_{0}^{l_{2}} \rho^{\alpha} \frac{k_{2}(x)}{k_{1}(x)} \frac{\mathrm{d} x}{d^{\beta}}=\frac{\rho^{\alpha}}{d^{\beta}} \int_{0}^{l_{2}} \frac{k_{2}(x)}{k_{1}(x)} \mathrm{d} x .
$$

根据定积分中值定理 ${ }^{[10]}$, 有

$$
\int_{0}^{l_{2}} \frac{k_{2}(x)}{k_{1}(x)} \mathrm{d} x=\mu(\eta) \int_{0}^{l_{2}} \mathrm{~d} x=k l_{2}
$$


式中 $k=\mu(\eta)\left(0 \leqslant \eta \leqslant l_{2}\right)$, 为一常数. 于是得到

$$
R_{\mathrm{DS}}=k \rho^{\alpha} \frac{l_{2}}{d^{\beta}},
$$

式 (4) 是所求解的拟合公式. 式 (4) 表明, 适当的选择经验参数 $\alpha, \beta$ 和 $k$, 可以得到单位宽度漏/源电 阻 $R_{\mathrm{DS}}$. 从物理意义来说, 拟合参数 $\alpha, \beta$ 和 $k$ 归纳了对于电阻值影响较小而又不易解析计算的因素, 如微元电阻高度 $h$ 不是常数、电阻率 $\rho$ 在整个区域不是常数和长度 $l_{0}$ 等, 只要正确地计算 $\alpha, \beta$ 和 $k$, 就可以得到电阻 $R_{\mathrm{DS}}$ 的精确值.

\section{3 经验参数的确定}

为了准确得到经验参数, 这里用统计的方法求经验参数 $\alpha, \beta$ 和 $k$. 统计的方法要有大量的电 阻 $R_{\mathrm{DS}}$ 与结构参数的数据和适当的算法. 下面先介绍如何用修正沟道电阻法 (correctional resistance method) ${ }^{[1,11,12]}$ 提取 MOSFET 器件漏/源电阻, 再讨论多元线性回归的最小二乘法求解公式.

\section{1 修正沟道电阻法提取 MOSFET 漏/源电阻}

对从实验参数提取 $R_{\mathrm{DS}}$ 的修正沟道电阻法略加改造, 就可以得到从仿真数据中提取 $R_{\mathrm{DS}}$ 的方法, 其原理可参考有关文献, 具体步骤如下:

(1) 用 silvaco 仿真一组沟道宽度相同、沟道长度 $L_{m}$ 不同 MOSFET 的 $I_{\mathrm{ds}}-V_{\mathrm{ds}}$ (伏安特性) 曲线, 栅源电压 $V_{\mathrm{gs}}$ 以 $0.01 \mathrm{~V}$ 的步长变化;

(2) 计算中需要用到 MOSFET 的阈值电压 $V_{\mathrm{th}}$, 已有很多文献介绍过阈值电压提取方法, 例如文 献 [13]. 为方便和准确, 我们用 silvaco 自带的 MOSFET 阈值电压提取程序从仿真的 MOSFET 伏安 特性曲线提取不同沟道长度 MOSFET 的 $V_{\mathrm{th}}$;

(3) 对于给定的栅电压 $V_{\mathrm{g}}$, 仿真不同沟道长度 $V_{\mathrm{g}}-V_{\mathrm{th}}$ 下的漏源电流 $I_{\mathrm{ds}}$, 计算 MOSFET 的输出 电阻 $R_{m}=\frac{V_{\mathrm{ds}}}{I_{\mathrm{ds}}}$, 在输出电阻与沟道长度坐标系中根据计算结果作出直线的二次线性回归, 并求出相应 的斜率 $A_{m}$ 和截距 $B_{m}$;

(4) 将栅电压的取值在 $1 \sim 3 \mathrm{~V}$ 范围内变化, 重复步骤 (3), 步长变化 $0.2 \mathrm{~V}$, 得到一组斜率 $A_{i}$ 和截 距 $B_{i}(i=1,2, \ldots)$;

(5) 作 $A_{i}$ 与 $B_{i}$ 的关系直线, 对 B-A 直线做二次线性回归, 得出的直线截距就是漏/源电阻, 上述 步骤 $(3) \sim(5)$ 不需要人工计算, 可用程序在 MATLAB 上实现.

\section{2 多元线性回归法表达式和经验参数的计算}

现介绍多元线性回归方法表达式. 设有 $t$ 个数据点, 如果这 $t$ 个点基本上在同一直线上, 多元回 归函数是 $[14]$

$$
y=a_{0}+\sum_{m=1}^{t} a_{m} x_{m}
$$

式中 $a_{1}, \ldots, a_{t}$ 是回归系数. 数据点取值是 $\left(x_{i 1}, x_{i 2}, \ldots, x_{i t}, y_{i}\right)(i=1,2, \ldots, m)$, 共有 $m$ 组数据. 求解 
该问题过程可参阅文献 $[14,15]$, 这里略去过程, 直接给出结论. 求解系数的方程组是

$$
\left\{\begin{array}{c}
a_{0}+x_{11} a_{1}+x_{12} a_{2}+\cdots+x_{1 t} a_{t}=y_{1}, \\
a_{0}+x_{21} a_{1}+x_{22} a_{2}+\cdots+x_{2 t} a_{t}=y_{2}, \\
\cdots \\
a_{0}+x_{m 1} a_{1}+x_{m 2} a_{2}+\cdots+x_{m t} a_{t}=y_{m},
\end{array}\right.
$$

式 (6) 的解 $\boldsymbol{a}=\left(a_{0}, a_{1}, \ldots, a_{t}\right)^{\mathrm{T}}$ 为所求多元线性回归系数, 可用 MATLAB 中的 regress 函数求解向 量 $\boldsymbol{a}=\left(a_{0}, a_{1}, \ldots, a_{t}\right)^{\mathrm{T}}$.

式 (4) 是指数表达式, 不能直接应用线性回归法. 为了用式 (6) 求解式 (4) 的经验参数 $\alpha, \beta$ 和 $k$, 对式 (4) 求对数, 得到

$$
\ln R_{\mathrm{DS}}-\ln l_{2}=\ln k+\alpha \ln \rho-\beta \ln d,
$$

其中, $\ln R_{\mathrm{DS} i}-\ln l_{2 i}$ 为因变量 $y_{i}(i=1,2, \ldots, m), \ln \rho_{i}$ 和 $\ln d_{i}$ 分别为自变量 $x_{i 1}(i=1,2, \ldots, m)$ 和 $x_{i 2}(i=1,2, \ldots, m)$; 将 $\ln k, \alpha$ 和 $\beta$ 分别当作 $a_{0}, a_{1}$ 和 $a_{2}$. silvaco 仿真可以得到 $m$ 组数据, 再用式 (6) 可以解出 $\ln k, \alpha$ 和 $\beta$, 从而得到最终解 $\alpha, \beta$ 和 $k$.

利用式 (4) 和多元线性回归法相结合计算漏/源电阻, 原则上只要知道 MOSFET 的漏/源电阻的 一些值, 就可以用此方法算出其半经验公式, 对于其参数如祄底掺杂浓度 $N_{A}$ 、漏/源区电阻率 $\rho$ 、 $p n$ 结的长度 $l$ 与深度 $d$ 、叠栅长度 $l_{1}$ 和 $l_{2}$ 并无特殊要求和限制, 其公式的形式只与样本集数据范围和 精度相关. 但是, 线性回归方法是一个统计的方法, 数据量愈大其结果越准确, 而大规模的数据量, 是 实验难以做到的. 解决大数据量的方法之一是依靠仿真方法求其漏/源电阻值. 因为 3.1 小节的修正沟 道电阻法提取电阻中的步骤 (3) 和 (4) 中, 希望以 $V_{\mathrm{gs}}-V_{\mathrm{th}}$ 为参数的输出电阻与沟道长度关系是线性 关系, 以便多个数据点聚在一条直线上 ${ }^{[1]}$, 这就要求阈值电压最好不随沟道长度变化, 至少变化要小. 而在 silvaco 仿真时发现, 对于沟道是 $30 \mathrm{~nm}$ 以下的 MOSFET, 阈值电压随沟道长度变化非常快, 稍微 减少一点沟道长度, 阈值电压就下降很多, 用沟道离子注入也很难抑制它的这种快速变化. 从数据的 可靠性出发, 我们以 $45 \mathrm{~nm}$ 沟道长度作为仿真求电阻时沟道长度的下限.

下面给出一个例子介绍漏/源电阻经验公式的一般形式和经验参数的量级. 考虑常见的情况, 取祄 底掺杂浓度 $N_{A}=1 \times 10^{15} \mathrm{~cm}^{-3}, h=1 \mathrm{~cm}$, 沟道长度是 $45 \sim 2000 \mathrm{~nm}$ 的 nMOSFET, 对它们沟道做适 当离子注入, 以保持它们阈值电压都在 $0.5 \sim 0.7 \mathrm{~V}$ 之间, 将这些参数下得到的漏/源电阻值代入式 (7) 可以算出半经验公式. 为了分析漏/源电阻 $R_{\mathrm{DS}}$ 与沟道长度的关系, 首先按照 MOSFET 的沟道长度 将它们分成 5 个区间, 每个区间取 30 组不同参数, 用本节的方法求出拟合参数 $\alpha, \beta$ 和 $k$, 所得漏/源 电阻表达式如表 1 所示.

将所有仿真数据不分沟道长度拟合, 对 150 组数据用多元线性回归拟合, 根据本节的方法计算, 若 以 $\mu \mathrm{m}$ 为长度单位, 则得到 $\alpha=0.8, \beta=0.74, k=4.81$, 于是有

$$
R_{\mathrm{DS}}=\rho^{0.80} \frac{4.81 \cdot l_{2}}{d^{0.74}}
$$

上式换算成国际单位制, 得到

$$
R_{\mathrm{DS}}=\rho^{0.80} \frac{6.2757 \times 10^{7} \cdot l_{2}}{d^{0.74}},
$$

式 (18) 和 (19) 可用来计算沟道长度为 $45 \sim 2000 \mathrm{~nm}$ nMOSFET 的漏/源电阻. 
表 1 按沟道分区间的漏/源电阻拟合公式

Table 1 The semi physical semi empirical formula of drain/source resistance between the different channel sections

\begin{tabular}{cllll}
\hline Channel length $(\mathrm{nm})$ & Formulas that the unit of length is $\mu \mathrm{m}$ & $\begin{array}{c}\text { Formulas of international unit system } \\
\text { (the unit of length is } m \text { ) }\end{array}$ \\
\hline $980 \sim 1980$ & $R_{\mathrm{DS}}=\rho^{0.76} \frac{6.87 \cdot l_{2}}{d^{0.6}}$ & $(8)$ & $R_{\mathrm{DS}}=\rho^{0.76} \frac{5.9334 \times 10^{7} \cdot l_{2}}{d^{0.6}}$ & $(9)$ \\
$580 \sim 980$ & $R_{\mathrm{DS}}=\rho^{0.77} \frac{6.27 \cdot l_{2}}{d^{0.63}}$ & $(10)$ & $R_{\mathrm{DS}}=\rho^{0.77} \frac{4.2173 \times 10^{7} \cdot l_{2}}{d^{0.63}}$ & $(11)$ \\
$120 \sim 200$ & $R_{\mathrm{DS}}=\rho^{0.82} \frac{3.63 \cdot l_{2}}{d^{0.8}}$ & $(12)$ & $R_{\mathrm{DS}}=\rho^{0.82} \frac{4.6832 \times 10^{6} \cdot l_{2}}{d^{0.8}}$ & $(13)$ \\
$80 \sim 120$ & $R_{\mathrm{DS}}=\rho^{0.82} \frac{5.40 \cdot l_{2}}{d^{0.72}}$ & $(14)$ & $R_{\mathrm{DS}}=\rho^{0.82} \frac{2.0555 \times 10^{7} \cdot l_{2}}{d^{0.72}}$ & $(15)$ \\
$45 \sim 80$ & $R_{\mathrm{DS}}=\rho^{0.83} \frac{9.21 \cdot l_{2}}{d^{0.58}}$ & $(16)$ & $R_{\mathrm{DS}}=\rho^{0.83} d \frac{1.3322 \times 10^{7} \cdot l_{2}}{d^{0.58}}$ & $(17)$ \\
\hline
\end{tabular}

\section{4 模型与仿真结果比较}

为了验证式 (4) 经验因子 $\alpha, \beta$ 和 $k$ 的正确性, 对第 3 节例子的式 (8) 和 (19) 做了计算验证. 取 nMOSFET 的祄底掺杂浓度为 $1 \times 10^{15} \mathrm{~cm}^{-3}$ 和 $1 \times 10^{16} \mathrm{~cm}^{-3}, h=1 \mathrm{~cm}$, 阈值电压经过离子注入都 在 $0.2 \sim 0.7 \mathrm{~V}$ 之间, 沟道长度范围是 $45 \sim 2000 \mathrm{~nm}$. 任意选取结构相同而物理参数不同的 MOSFET, 用 silvaco 软件仿真它们的伏安特性, 然后用修正沟道电阻法提取漏/源电阻, 将它们与文章里所给出的公 式计算结果相比较.

祄底掺杂浓度是 $1 \times 10^{15} \mathrm{~cm}^{-3}$ MOSFET 的计算与仿真结果如图 3 5 所示. 这些结果表明式 (18) 是高精度的计算公式, 最大误差为 $9 \%$.

祄底掺杂浓度为 $1 \times 10^{16} \mathrm{~cm}^{-3}$ 的 MOSFET, 仅在图 6 给出了沟道长度是 $45 \sim 80 \mathrm{~nm}, 120 \sim 200 \mathrm{~nm}$ 时, 改变结深 $d$ 大小, 漏/源电阻仿真值与公式计算值结果, 最大误差为 $9.5 \%$.

从图 3 6 中结果误差对比可知, 在一定的沟道长度取值范围时, 部分分区间 (指不同沟道长度取 值范围) 公式计算结果精度稍差, 大部分情况下分区间计算公式与式 (18) 的精度是相近的, 即统一的 计算公式与分区间的计算公式得到的电阻值相差不大, 都有很高的精度. 这表明虽然沟长对其漏/源电 阻计算公式略有影响, 但是通过 $\alpha, \beta$ 和 $k$ 的调整, 最终结果相差不多, 从而说明沟道长度对漏/源电 阻影响较小.

深亚微米 MOSFET 漏/源通常是 LDD 结构, 本文论述的模型对 LDD 结构也是适用的, 图 7 是 一个计算实例, 其误差与前面例子在同一量级.

从电磁场理论可知, 均匀电阻率情况下的载流子在导电区域若只做漂移运动, 则其电势分布满足 Laplace 方程, 这样得到的电阻值与电阻率是线性关系 ${ }^{[16]}$. 而从计算公式可见, 漏/源本征电阻值与电 阻率的关系不是线性关系, 这说明载流子在漏/源区不是单纯的漂移运动, 将有一些扩散运动. 由此可 以推断漏/源区电势分布的微分方程将不再是 Laplace 方程而是更为复杂的漂移扩散方程, 其结果也 是复杂、繁琐的, 不一定有解析解, 因此电阻表达式也将是复杂、繁琐的, 这说明了文章所给出的半经 验公式 (4) 和用统计的方法计算经验参数的合理性.

根据式 (18) 和计算验证结果, 可以得到以下结论: MOSFET 漏/源电阻大小主要取决于 3 个物理 参数, 分别为: 器件漏/源区域的结深 $d$ 、掺杂电阻率 $\rho$ 以及沟道末端到漏/源电极的距离 $l_{2}$. 而漏/源 区叠栅长度 $l_{1}$ 和漏/源电极的尺寸 $l_{0}$ 对漏/源电阻的影响基本可以忽略. 这些结论, 可以指导我们深 入地认识和理解 MOS 器件的物理参数与漏/源电阻的关系. 


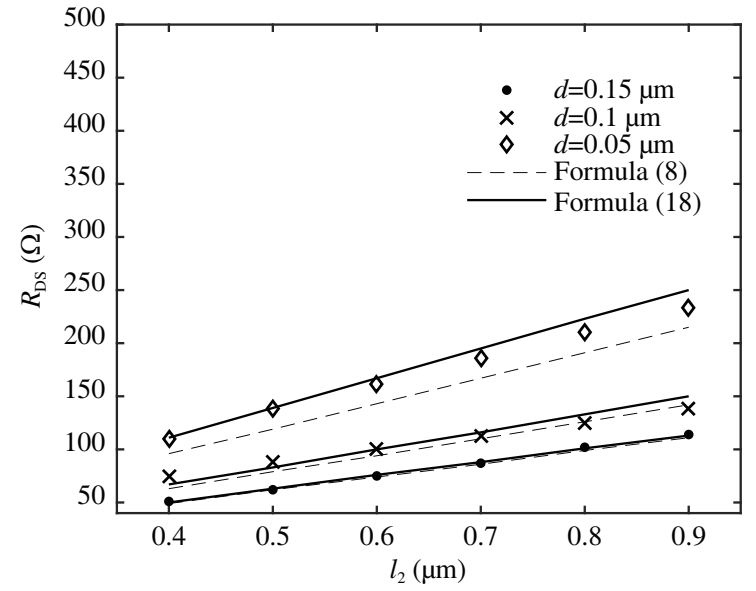

(a)

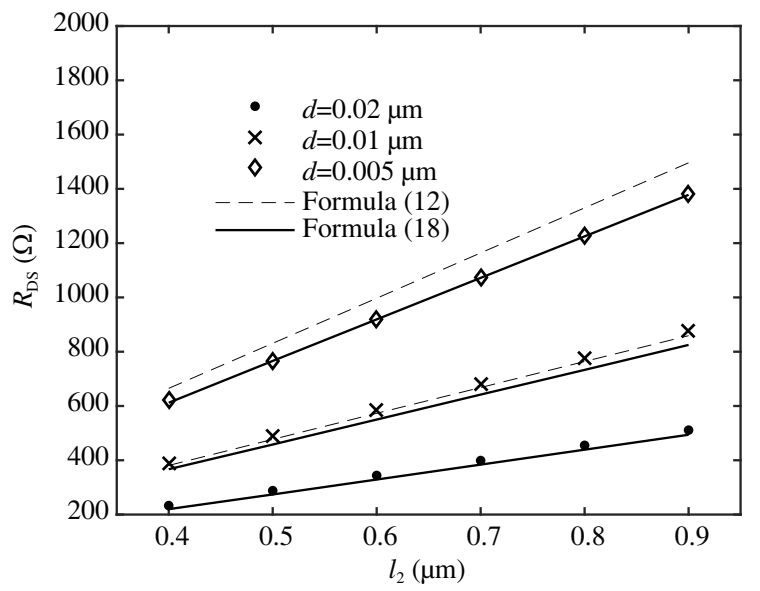

(b)

图 3 (a) 沟道为 $1000 \sim 2000 \mathrm{~nm}, l=1.6 \mu \mathrm{m}, l_{1}=0.01 \mu \mathrm{m}, \rho=10 \Omega \cdot \mu \mathrm{m}$, 改变 $l_{1}$ 的值, 漏/源电阻仿真值 与公式计算值对比, 式 (18) 的最大误差是 $5 \%$, 式 (8) 的最大误差是 $5 \%$; (b) $l=1.6 \mu \mathrm{m}, l_{1}=0.01 \mu \mathrm{m}, \rho=$ $10 \Omega \cdot \mu \mathrm{m}$ 沟道长度是 $120 \sim 200 \mathrm{~nm}$, 改变漏区电阻率 $l_{2}$, 漏/源电阻仿真结果, 式 $(18)$ 的最大误差是 $5.9 \%$, 式 (12) 的最大误差是 $8 \%$

Figure 3 (a) is comparison of simulation values of drain / source resistance and formula calculation when $l_{2}$ changed and channel length is $1000 \sim 2000 \mathrm{~nm}, l=1.6 \mu \mathrm{m}, l_{1}=0.01 \mu \mathrm{m}, \rho=10 \Omega \cdot \mu \mathrm{m}$. The maximum error of $(18)$ is $5 \%$, and for $(8)$ is $5 \%$. (b) is simulation results of drain / source resistance when $l_{2}$ changed and channel length is $120 \sim 200 \mathrm{~nm}, l=1.6 \mu \mathrm{m}$, $l_{1}=0.01 \mu \mathrm{m}, \rho=10 \Omega \cdot \mu \mathrm{m}$. The maximum error of $(18)$ is $5.9 \%$, and for $(12)$ is $8 \%$

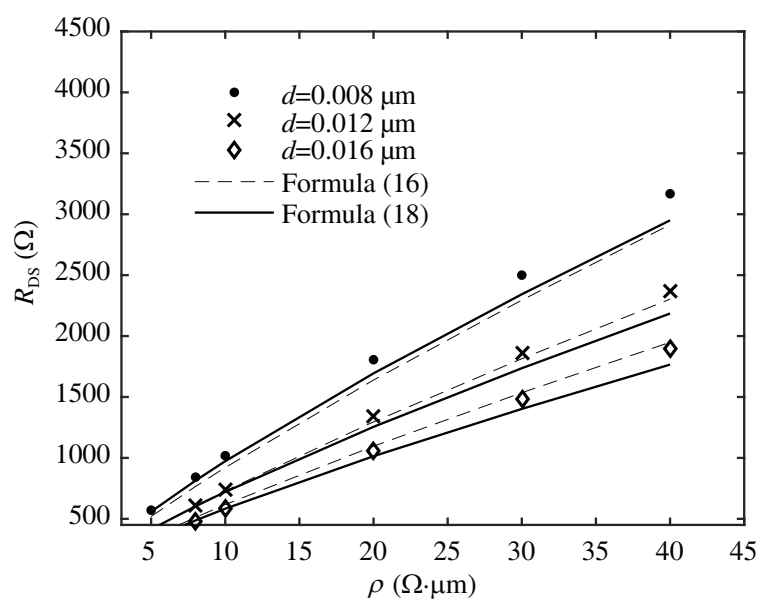

(a)

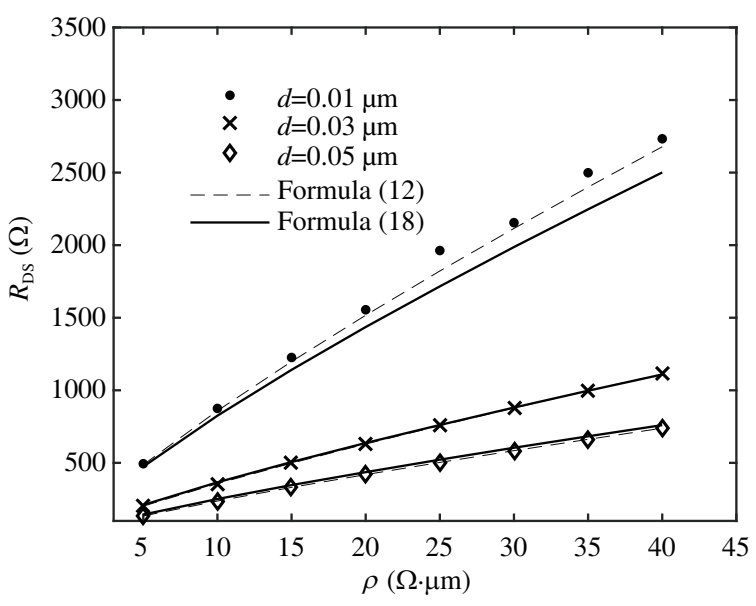

(b)

图 4 (a) 沟道为 $45 \sim 80 \mathrm{~nm}, l=1.6 \mu \mathrm{m}, l_{1}=0.01 \mu \mathrm{m}, l_{2}=0.9 \mu \mathrm{m}$, 改变电阻率 $\rho$, 漏/源电阻仿真值与 公式计算值对比, 式 (18) 的最大误差是 $6.6 \%$, 式 (16) 的最大误差是 $9 \%$; 图 (b) $l=1.6 \mu \mathrm{m}, l_{1}=0.01 \mu \mathrm{m}$, $l_{2}=0.9 \mu \mathrm{m}$, 沟道长度是 $120 \sim 200 \mathrm{~nm}$, 改变漏区电阻率 $\rho$, 漏/源电阻仿真结果, 式 $(18)$ 的最大误差是 $7.7 \%$, 式 (12) 的最大误差是 $5 \%$

Figure 4 (a) is comparison of simulation values of drain/source resistance and formula calculation when $\rho$ changed and channel length is $45 \sim 80 \mathrm{~nm}, l=1.6 \mu \mathrm{m}, l_{1}=0.01 \mu \mathrm{m}, l_{2}=0.9 \mu \mathrm{m}$. The maximum error of (18) is $6.6 \%$, and for (16) is $9 \%$. (b) is simulation results of drain/source resistance when changed and channel length is $120 \sim 200 \mathrm{~nm}, l=1.6 \mu \mathrm{m}, l_{1}=$ $0.01 \mu \mathrm{m}, l_{2}=0.9 \mu \mathrm{m}$. The maximum error of (18) is $7.7 \%$, and for (12) is $5 \%$ 


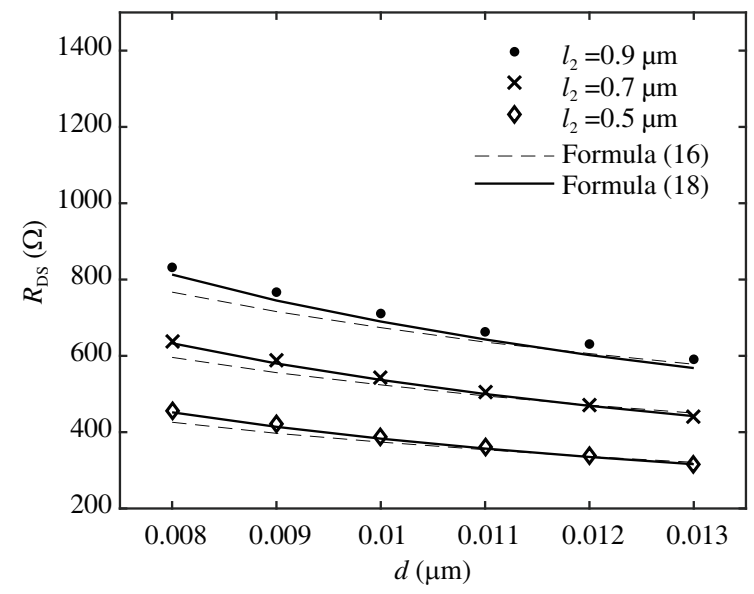

(a)

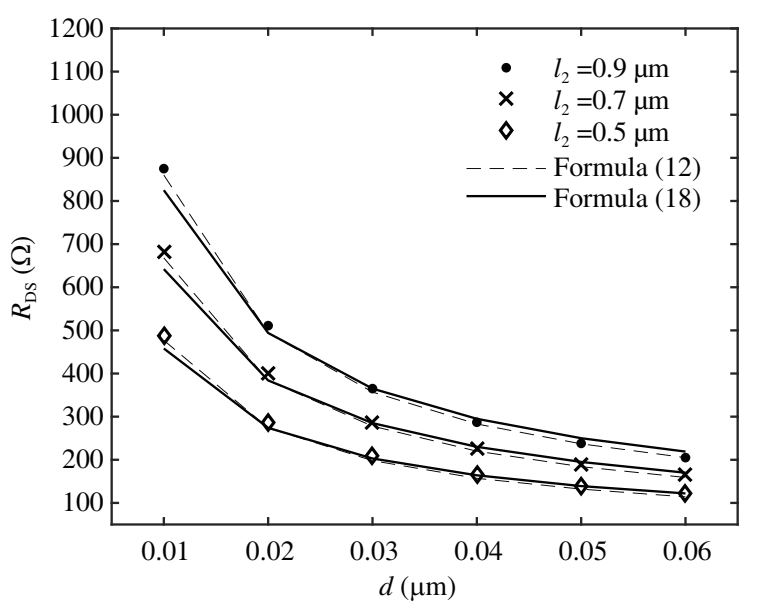

(b)

图 5 (a) 沟道为 $45 \sim 80 \mathrm{~nm}, l=1.6 \mu \mathrm{m}, l_{1}=0.01 \mu \mathrm{m}, \rho=8 \Omega \cdot \mu \mathrm{m}$, 改变结深 $d$ 大小, 漏/源电阻仿真值与 公式计算值对比, 式 (18) 的最大误差是 $6.9 \%$, 式 (16) 的最大误差是 $8.6 \%$; (b) $l=1.6 \mu \mathrm{m}, l_{1}=0.01 \mu \mathrm{m}, \rho$ $=10 \Omega \cdot \mu \mathrm{m}$, 沟道长度是 $120 \sim 200 \mathrm{~nm}$, 改变结深 $d$, 漏/源电阻仿真结果, 式 (18) 的最大误差是 $3.9 \%$, 式 (12)

\section{的最大误差是 $8.5 \%$}

Figure 5 (a) is comparison of simulation values of drain/source resistance and formula calculation when $d$ changed and channel length is $45 \sim 80 \mathrm{~nm}, l=1.6 \mu \mathrm{m}, l_{1}=0.01 \mu \mathrm{m}, \rho=8 \Omega \cdot \mu \mathrm{m}$. The maximum error of (18) is $6.9 \%$, and for (16) is $8.6 \%$. (b) is simulation results of drain/source resistance when $l_{2}$ changed and channel length is $120 \sim 200 \mathrm{~nm}, l=1.6 \mu \mathrm{m}$, $l_{1}=0.01 \mu \mathrm{m}, \rho=10 \Omega \cdot \mu \mathrm{m}$ The maximum error of (18) is $3.9 \%$, and for (12) is $8.5 \%$

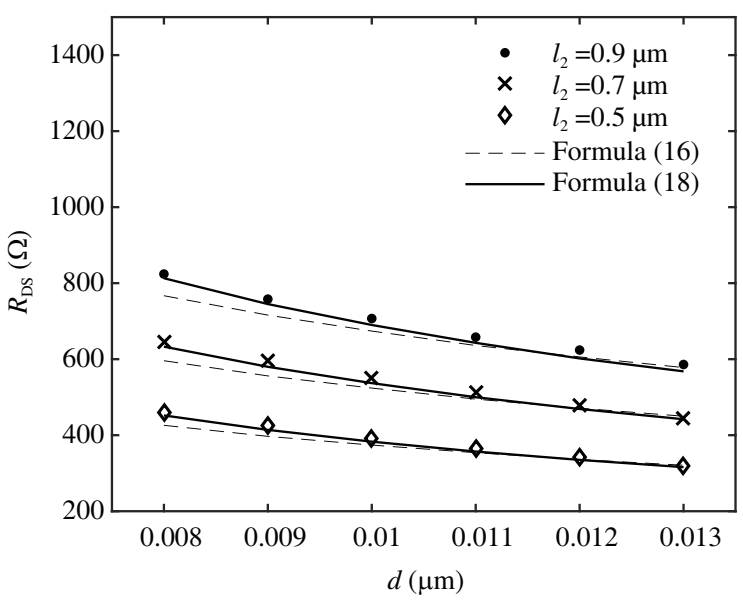

(a)

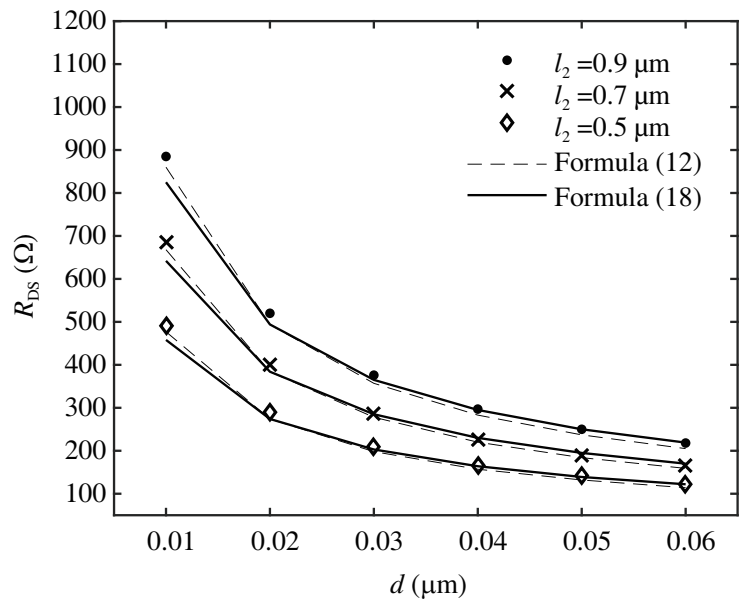

(b)

图 6 (a) 沟道为 $45 \sim 80 \mathrm{~nm}, l=1.6 \mu \mathrm{m}, l_{1}=0.01 \mu \mathrm{m}, \rho=10 \Omega \cdot \mu \mathrm{m}$, 改变结深 $d$ 大小, 漏/源电阻仿真值与 公式计算值对比, 式 (18) 的最大误差是 $6.9 \%$, 式 (16) 的最大误差是 9.5\%; (b) $l=1.6 \mu \mathrm{m}, l_{1}=0.01 \mu \mathrm{m}, \rho$ $=10 \Omega \cdot \mu \mathrm{m}$, 沟道长度是 $120 \sim 200 \mathrm{~nm}$, 改变结深 $d$, 漏/源电阻仿真结果, 式 $(18)$ 的最大误差是 $3.9 \%$, 式 $(12)$ 的最大误差是 $8.5 \%$

Figure 6 (a) is comparison of simulation values of drain/source resistance and formula calculation when changed and channel length is $45 \sim 80 \mathrm{~nm}, l=1.6 \mu \mathrm{m}, l_{1}=0.01 \mu \mathrm{m}, \rho=8 \Omega \cdot \mu \mathrm{m}$. The maximum error of (18) is $6.9 \%$, and for (16) is $9.5 \%$. (b) is simulation results of drain/source resistance when changed and channel length is $120 \sim 200 \mathrm{~nm}, 45 \sim 80 \mathrm{~nm}, l=$ $1.6 \mu \mathrm{m}, l_{1}=0.01 \mu \mathrm{m}, \rho=10 \Omega \cdot \mu \mathrm{m}$. The maximum error of (18) is $3.9 \%$, and for (12) is $8.5 \%$ 


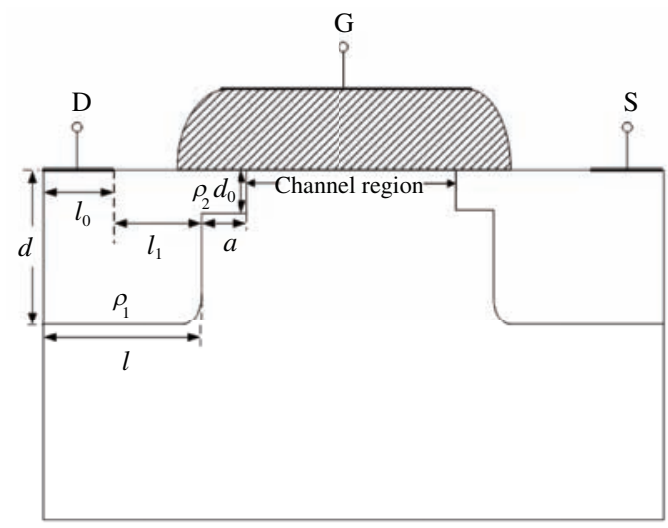

(a)

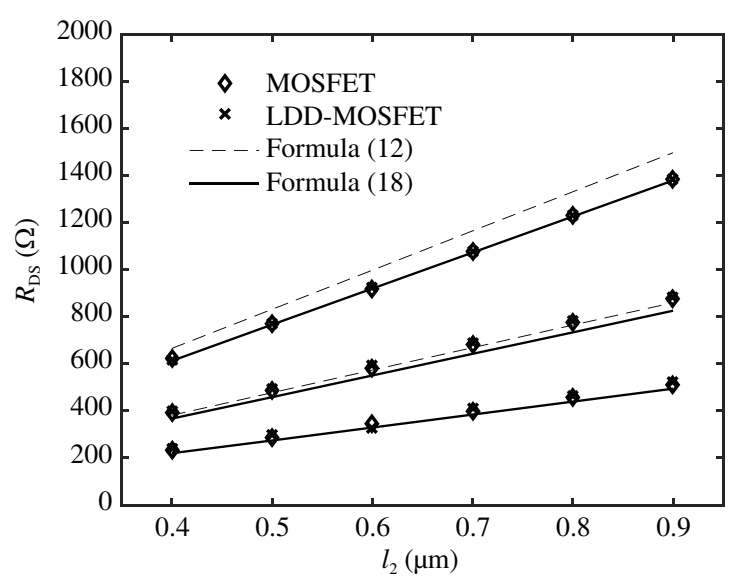

(b)

图 7 (a) 是沟道长度 $120 \sim 200 \mathrm{~nm}$, 尺寸为 $l=1.6 \mu \mathrm{m}, l_{1}=0.01 \mu \mathrm{m}, \rho_{1}=10 \Omega \cdot \mu \mathrm{m}, \rho_{2}=100 \Omega \cdot \mu \mathrm{m}$, $a=0.01 \mu \mathrm{m}, d=0.002 \mu \mathrm{m}$ 的 LDD 结构; (b) 取三组结深 $d$ 分别为 $0.02 \mu \mathrm{m}, 0.01 \mu \mathrm{m}$ 和 $0.005 \mu \mathrm{m}$, 改变 $l_{2}$, 普通 MOSFET 和 LDD-MOSFET 漏/源电阻仿真结果, 式 (18) 的最大误差是 $8.4 \%$, 式 (12) 的最大误差 是 $8.5 \%$

Figure 7 (a) is the structure that channel length is $120 \sim 200 \mathrm{~nm}, l=1.6 \mu \mathrm{m}, l_{1}=0.01 \mu \mathrm{m}, \rho_{1}=10 \Omega \cdot \mu \mathrm{m}, \rho_{2}=$ $100 \Omega \cdot \mu \mathrm{m}, a=0.01 \mu \mathrm{m}, d=0.002 \mu \mathrm{m}$. (b) is comparison of simulation results of normal MOSFET's and LDD-MOSFET's drain/source resistance when $l_{2}$ changed and $d$ is $0.02 \mu \mathrm{m}, 0.01 \mu \mathrm{m}$ and $0.005 \mu \mathrm{m}$ respectively. The maximum error of (18) is $8.4 \%$, and for $(12)$ is $8.5 \%$

\section{5 结束语}

本文根据微分电阻的概念和器件的数值模拟结果, 提出了漏/源本征电阻的半经验计算公式 (4) 和祄底掺杂浓度是 $1 \times 10^{15} \mathrm{~cm}^{-3}$ 和 $1 \times 10^{16} \mathrm{~cm}^{-3}$ 、阈值电压在 $0.5 \sim 0.7 \mathrm{~V}$ 之间、45 2000 $\mathrm{nm}$ 沟长 nMOSFET 的漏/源本征电阻计算公式 (18), 给出了求解经验参数的算法. 从给出的公式及其计算结果 可知, 影响器件漏/源电阻的主要物理参数分别是: 器件漏/源区域的结深 $d$ 、掺杂电阻率 $\rho$ 以及沟道 到漏/源电极的距离 $l_{2}$. 而漏/源区叠栅长度 $l_{1}$ 和漏/源区电极的大小对漏/源本征电阻的影响基本可 以忽略. 经过计算验证, 漏/源电阻计算公式计算结果与 silvaco 软件仿真得到的电阻值结果相近、误 差小, 因此 MOSFET 的漏/源本征电阻可用公式 (4) 计算. 此计算公式形式简单、精度高、物理参数与 漏/源电阻关系明确, 经验参数易于提取. 文章给出的漏/源电阻简单计算公式可以直接用于 MOSFET 特性分析和电路模拟器的 MOS 晶体管的漏/源电阻值计算, 由于计算公式不牵涉半导体物理、计算量 小且结果准确, 易于电路设计工程师理解和接受, 方便了集成电路设计. 对器件研究者来说, 可以更深 入地认识和理解 MOS 晶体管的物理和几何参数与漏/源电阻关系.

\section{参考文献}

1 Hu C C. Modern Semiconductor Devices for Integrated Circuits. Beijing: Publishing House of Electronics Industry, 2012. 168-171 [胡正明, 著. 王燕, 张莉, 叶佐昌, 等译. 现代集成电路半导体器件. 北京: 电子工业出版社, 2012. $168-171]$

2 Stephen D S. Microsystem Design. Beijing: Publishing House of Electronics Industry, 2004. 182 [Stephen D S, 著. 刘 泽文, 王晓红, 黄庆安, 等译. 微系统设计. 北京: 电子工业出版社, 2004. 182]

3 Bae H, Jang J, Shin J S, et al. Modeling and separate extraction of gate-bias- and channel-length-dependent intrinsic 
and extrinsic source drain resistances in MOSFETs. IEEE Electron Device Lett, 2011, 32: 722-724

4 Chang Y H, Liu Y J. A new extraction method for source/drain resistance in MOSFETs. In: Proceedings of the 10th IEEE International Conference Solid-State and Integrated Circuit Technology (ICSICT), Shanghai, 2010. 1910-1912

5 Chen L, Sun L L, Liu J. Surface-potential-based analysis of bias-dependent series resistance in LDD MOSFET. In: Proceedings of IEEE 8th International Conference ASIC, Changsha, 2009. 1244-1246

6 He P, Ke D, Hu P. Two-dimensional physically based semi-analytical model of source/drain series resistance in MOSFETs. Japanese J Appl Phys, 2015, 55: 014302

7 Ng K K, Lynch W T. The impact of intrinsic series resistance on MOSFET scaling. IEEE Trans Electron Device, 1986, 34: 27-28

8 Shur M, Rumyantsev S, Levinshtein M. SiC Materials and Devices. Beijing: Publishing House of Electronics Industry, 2012. 60-61 [Shur M, Rumyantsev S, Levinshtein M, 著. 杨银堂, 贾护军, 段宝兴, 译. 碳化硅半导体材料与器件. 北 京: 电子工业出版社, 2012.60-61]

9 甘学温, 黄如, 刘晓彦, 等. 纳米 CMOS 器件. 北京: 科学出版社, 2004. 50

10 陈纪修, 於崇华, 金路. 数学分析 (第二版) 上册. 北京: 高等教育出版社, 2004. 290-291

11 Taur Y, Ning T H. Fundamentals of Modern VLSI Devices. New York: Cambridge University Press, 1998. 244

12 Yang L A, Yu C L, Hao Y. Channel resistance method for parameter extraction of ultra-thin gate oxide LDD MOSFET's. In: Proceedings of the 8th International Conference on Solid-State and Integrated Circuit Technology, Shanghai, 2006. 1373-1375

13 Zhao Y, Parke S, Burkr F. Modeling and characterization of deep-submicron MOSFET with short-channel effect based on BSIMTM. Acta Electron Sin, 2004, 5: 841-844 [赵阳, Parke S, Burke F. 基于 BSIM 深亚微米级 MOSFET 短沟 道效应建模和特征提取方法研究. 电子学报, 2004, 5: 841-844]

14 Arora N. MOSFET Models for VLSI Circuit Simulation Theory and Practice. Beijing: Science Press, 1999. 631-632 [Arora N, 著. 张兴, 李映雪, 等译. 用于 VLSI 模拟的小尺寸 MOS 器件模型理论与实践. 北京: 科学出版社, 1999. 631-632]

15 Burden R L, Faires J D. Numerical Analysis. 7th ed. Beijing: Higher Education Press, 2005. $432-440$ [Burden R L, Faires J D, 著. 冯烟利, 朱海燕, 译. 数值分析 (第七版). 北京: 高等教育出版社, 2005. 432-440]

16 周省三. 电磁场基本教程. 北京: 高等教育出版社, 1987. 76-81 


\title{
A semi-empirical model of the drain/source resistance for MOSFET
}

\author{
Daoming KE*, Jianguo YANG, Hong CHANG, Fei YANG, Pengfei HU, \\ Xueyang PENG, Leshang SUN \& Di WU \\ School of Electronics and Information Engineering, Anhui University, Hefei 230601, China \\ * Corresponding author. E-mail: kedaoming@sohu.com
}

\begin{abstract}
A series resistance model is developed to accurately predict the drain/source resistance of MOSFETs in the ultra submicron regime. The series resistance model is based on the differential resistance concept and the mean value theorem of integrals. Three parameters of the model may be obtained through the multiple linear regression method. In this study, we employ numerical simulation data to fit three parameters for the planar nMOSFETs and nLDD-MOSFETs, of which the substrate doped concentration is $1 \times 10^{15} \sim 1 \times 10^{16} \mathrm{~cm}^{-3}$, and the channel length is $45 \sim 2000 \mathrm{~nm}$. We also obtain a semi-empirical formula with a maximum error of only 9.5\%. The theoretical model and calculation results of its semi-empirical formula show that the drain/source resistance is only related to the depth of the drain/source pn junction, resistivity, and length from the channel to the drain/source electrode, and that the influence of the channel length, stack-gate length, and electrode length is negligible. Because the semi-empirical formula is simple, with high precision and a clear physical concept, and allows for easy parameter extraction, it can be used in a characteristic analysis of MOSFETs and circuit simulators.
\end{abstract}

Keywords drain/source resistance of MOSFET, semi-empirical formula, infinitesimal resistance, numerical simulation

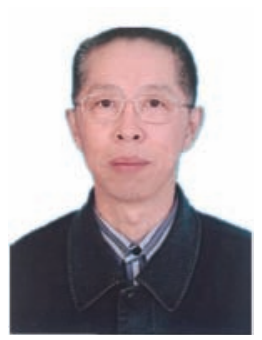

Daoming KE was born in July 1954. He received his Ph.D. degree from Southeast China University in October 1992, and is currently a professor at Anhui University. His main research direction is in the physics of semiconductor devices.

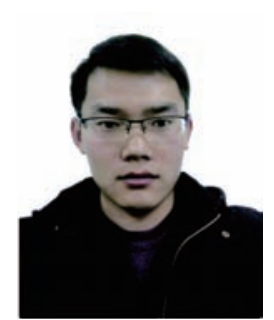

Jianguo YANG was born in June 1992. He is currently a graduate student at Anhui University, where his interests are in circuits and systems. His main research direction is in the physics of semiconductor devices. 